\title{
THE PURIFICATION OF WATER BY OZONE.
}

\author{
By S. RIDFAI, D.Sc., F.I.C. \\ (NELLOW.)
}

Read at Sessional Meeting, London, January 13th, 1909.

$\mathrm{ZONE}$ is the ideal agent for purifying, since it leaves behind it only
ordinary oxygen and nothing foreign to the water. It was first tried for this purpose by Fröhlich,' and Ohmüller proved that it energetically attacked bacteria in water from which any excess of inert organic matter had been previously removed." These experiments followed the construction of large industrial ozonisers by Siemens and IIalske at Berlin, who in 1898 erected an experimental plant at Martinikenfelde, and afterwards larger installations for the towns of Wiesbaden and Paderborn." Air ozonised to $2 \frac{1}{2}-3$ grams per cubic metre passed upwarls through a tower filled with flints, and met a descending current of roughly filtered water. The cost was about $2 \frac{3}{4} \mathrm{~d}$. per 1,000 gallons of water treated, and a very impure water was sterilised down to 2 to 9 organisms per cc. Earlier, in 1893, Tindal started his apparatus at Oudshoorn, Holland, and in 1895 worked it experimentally at Paris, also at Brussels and Blankenberghe, and it was adopted for limited supplies at sereral other places. The estimated cost was $0 \cdot 45 \mathrm{~d}$. per 1,000 gallons. The bacterial reports of Van Ermengem, Marmier and Roux were satisfactory." Tindal's apparatus obtained intimate admixture and duration of contact by passing the water and ozonised air either in the same or an opposite direction through towers divided by perforated diaphragms "or other equivalent dispositions"; anuther form had pulverisers or spray jets; and the partially exhausted air at the exit could be dried, re-ozonised, and returned. Subsequently, in 1897, appeared the Marmier-Abraham ${ }^{5}$ and

${ }^{1}$ Elektrotechn. Zett., 1891, 344.

Arbeit. Kais. Gesumd., 1892, 2.29.

${ }^{3}$ Zeits. f. Elektrochem., Nov. 14th, 1901. and 27 th, 1902.

$\checkmark$ liev. yén. des Sciences, 1896, 596.

3 Tried at Lille, 1898 ; in use at Cosue and Chartres. See also Ann. Inst. Purteur, 18リ5, ix.,1. 1773; Elentrochem. Ind., Feb., 1903, and Eckiraye Electrique, Dec. 12th, 1903. 
Otto patents; the former had a mixing tower filled with flints or bricks, the latter injected the water and ozonised air together by means of a pulveriser called an "emulsor," and later (1905) added a column of flints, through which a second current of air was ascending. These patents are now amalgamated, and are at work on the town supplies of Nice and Dinard, and (experimentally) at St. Maur, Paris. Tindal's previous patent, after his death, was acquired by De Frise, who has improved the apparatus and process, and has. introduced into his plant an ozoniser identical with the Siemens-Halske form, and an ozone-recuperating circuit.

In September and October, 1908, I examined in detail the working of De Frise's installation for the sterilization of water by ozone at the St. Maur Municipal Waterworks of the city of Paris. These municipal waterworks furnish a large portion of the water supply of Paris, drawn from the river Marne, a stream which receives a considerable amount of sewage pollution above the intake. At the time of my visit the river was full, with a sluggish flow; the water was greenish-brown, slightly turbid, had a faint marshy odour, and contained large numbers of aquatic organisms.

At the works, for the ordinary supply, the water is pumped into sedimentation reservoirs, then drawn off and filtered through gravel and sand. I found that the filtrate had no odour, was clear, and in small: quantities was practically colourless; in bulk it had a varying tint of greenish-brown. On the surface of the water in the reservoirs, and in the channels, gelatinous green masses containing water alga were frequent. The straining beds of gravel and sand did not completely remove these organisms, and the water which passed through them, although generally clear, was by no means pure or safe, as shown by my bacterial and chemical investigations, the results of which are recorded in the appended tables. It is obvious that further precantion is imperative, that the present reliance on filtration alone implies constant danger from pathogenic bacteria, and that sterilization, as far as it can be practically effected, is an urgent need.

For this purpose ozone has always seemed a most suitable and natural/ agent for two chief reasons :-

1. It is only a more active form of ordinary oxygen, already existing normally in small quantities in the atmosphere, and continually assisting in natural oxidations.

2. It adds no residue of any chemical to the water, and in doing its work of purification it is simply resolved into ordinary oxygen, which dissolves in the water and adds slightly to its aeration.

vou. IIx. No. 1 . 
Experience and researches' have proved that it is more economical and practical to supply the ozone in a state of large dilution with air, aroiding

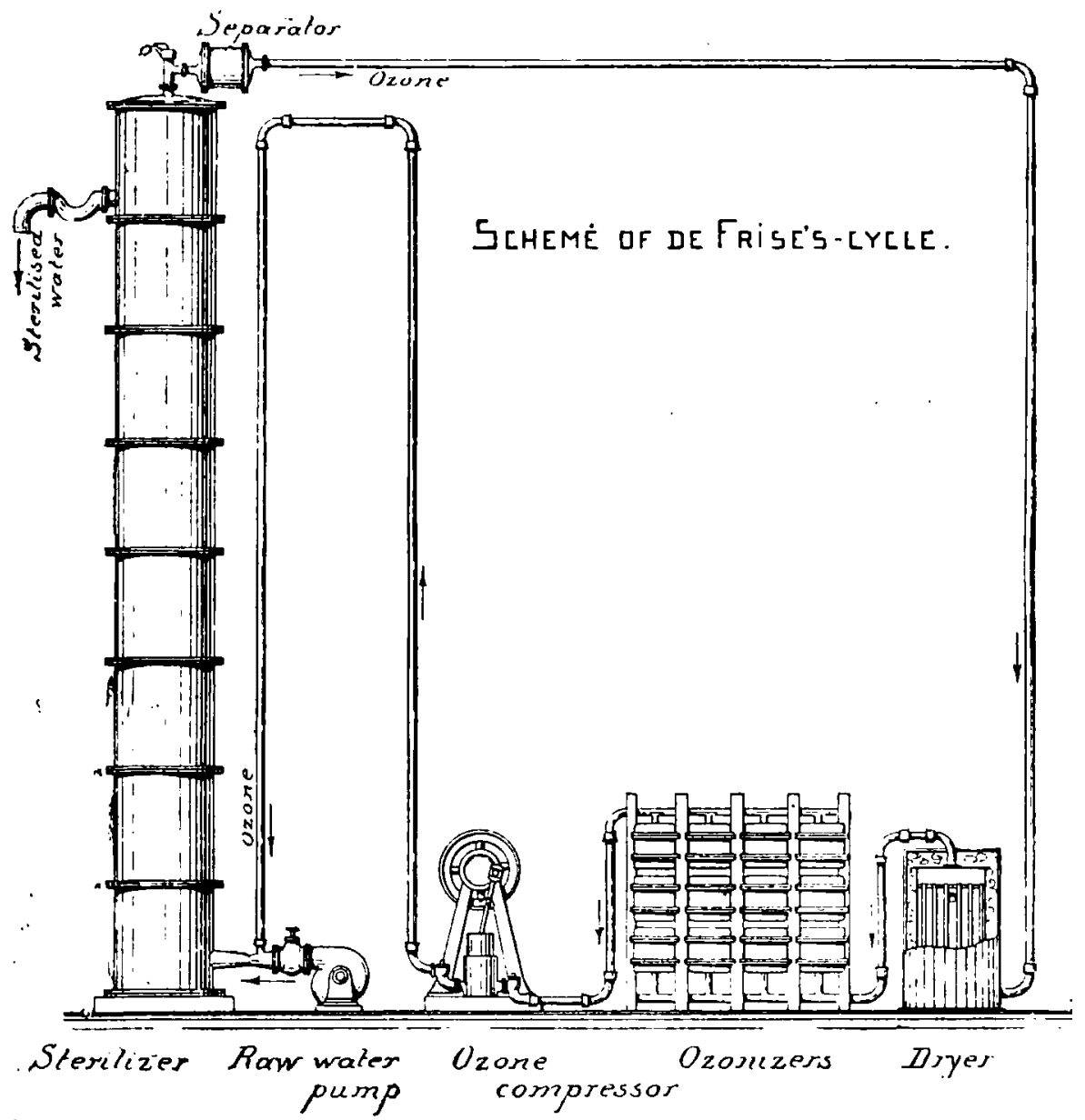

Fig. 1.

The ozove compressor draws the ozonised air from the uzonisers and forces it intu the steriliser; from the top of the steriliser the air returns to the ozonisers, passing on its way through \& separator ind a dryer in which it comes in contact with calcium clloride, which is cooled down in hot weather. A small suction valve on the iulet of the separator admits fresh air to make up for the loss through absorption by the sterilised water.

The air compressor used ut St. Mraur is a rertical double-acting pump, with $150 \mathrm{~mm}$. diameter of eylinder and $200 \mathrm{mw}$. struke of pistou, and was worked in October last at 140 revolutions per minute.

'Among othera, Classy found (Comptes rendlus, cxxxiii., p. 889) that a strength of seven per cent. in ozone cost in electrical energy niuety times as much as half per cent., so that it is best to only feebly enrich the oxygen, while nccelerating the circulation of gas. I have referred to this further in a paper in the Journal of the Society of Arts, 1902, p. 758 . 
contamination with nitrous compounds or other impurities, and in a series of careful tests $I$ observed that the Siemens-De Frise ozonisers now in use at these works yield the gaseous mixture in a very pure state, as will be seen by my subsequent record of chemical results.

The plant (Fig. 1) consists of an efficient arrangement for the production of ozonised air and for its intimate admixture with the water. The

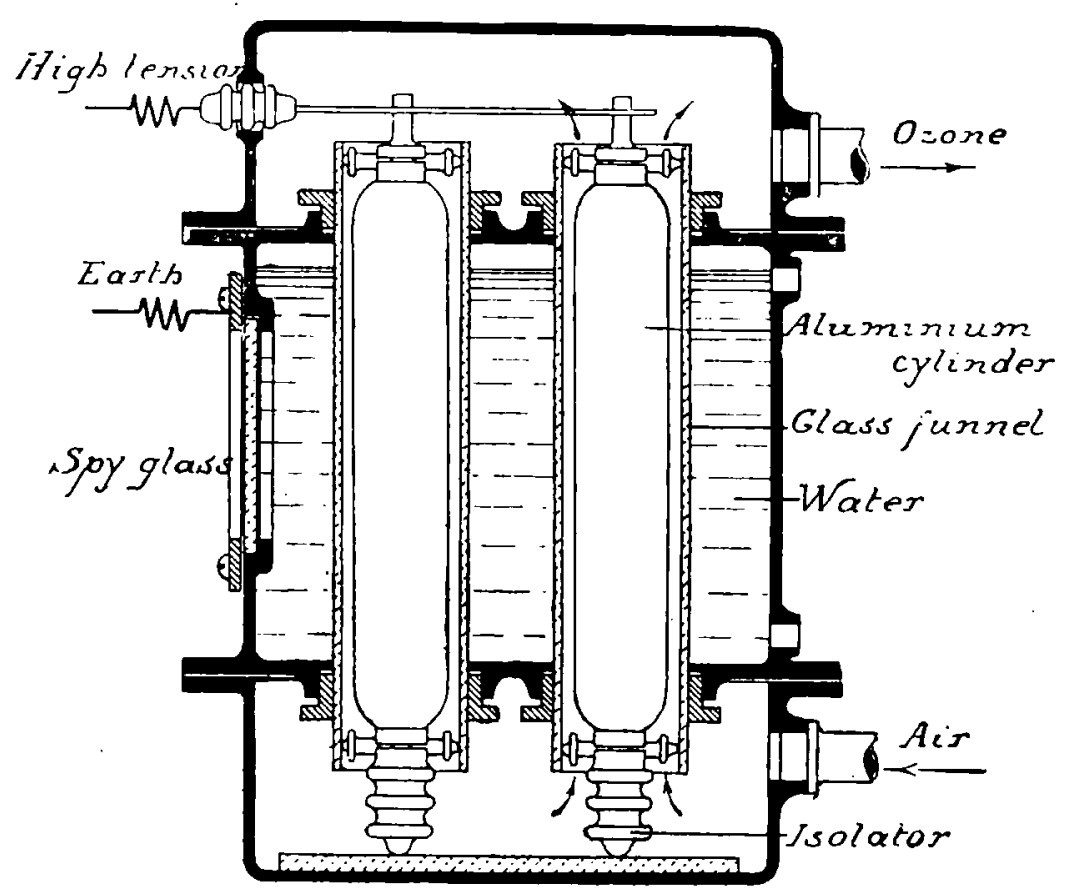

Fig. 2.

All ozoniser, comsisting of a lectangular cast-iron box divilen into three compartments by two tube plates into which glass cylinders are lacked by menus of screwed glands. Aluminium cylinder's, elosed at botll ededs, ale placed cuncentrically to the glass ones. The aluminimur cylinders are connected with one of the terminals of a step-lu, trausformer, the second terminal of which is edrthed. Cooling water circulntes through the central compartment, which is earthed. silent clischarge takes place in the space, one-sixteenth of an inch wide, between the glass and aluminium cylinders. The ar enters througl the lottom compartment, traverses the silent discharges, and leaves the ozoniser through the top compartment. 'There are eight sets of cylinglers per hox.

current was generated ly means of a 45 h.p. steam engine and a Mordey alternator of 110 rolts, and changed by a transformer to 4,000 volts.

The ozonisers were of the Siemens-Halske type (Fig. 2), placed in a lark rool room. In my experiments from Monday, September 28 th to Tuesday, October bth, there were six of these uzonisers running. (In Wednesday, October 7th, I caused the number of ozoniser's at work to be 
increased to nine, in order to ascertain what effect would be produced in the treatment by an increase of the electrical power employed. I have given the electrical factors in Table I., which also notes the amount of ozone in the air entering and in the water discharged. The ozonisers were working throughout in a very steady and quiet way and without sparking. ('areful tests showed that the power was also kept almost regular. The electrical energy required for the production of the ozorie during my experiments averaged 1.31 K.W.Hrs. per 104 cubic metres of water sterilised, equal to 57 B.T.U. per million gallons. In addition, the energy roquired for compression, $1.675 \mathrm{~K}$.W.Hrs. per 100 cubic metres (or 76 B.T.U. per million gallons), must be added to the cost, giving a total of 133 B.T.U. per million gallons.

I understand that M. C'olmet Daage, the Chief Engineer to the Paris Municipality, taking $\cdot 11 \mathrm{fr}$. as the price per kilowatt-hour (being that charged by the Société de l'Est Parisien), estimates the average cost of treatment at $\cdot 0184 \mathrm{fr}$. per cubic metre. He further estimates that for treatment of 300 cubic metres at an electrical cost of $055 \mathrm{fr}$. per kilowatthour, the expense would only be $\cdot 0072 \mathrm{fr}$. per cubic metre, say one-third of a penny per 1000 gallons, excluding interest, amortisation, and repairs.

The ozonised air was introduced laterally into the stream of filtered water in a proportion which was kept constant throughout the run, the volume of filtered water being 104 cubic metres per hour, equal to 22,880 gallons, and that of the ozonised air 42 cubic metres per hour (1,483 cubic feet), so that the volume of ozonised air supplied averaged 40.4 per cent. of the volume of filtered water treated.

During the main portion of the trial, from September 28 th to October bth, I found that the content of ozone in the air supplied was almost constant, as will be seen in Table $I$. : the lowest amount in grammes of ozone per cubic metre of air entering being 1.45 on the morning of September 30th, and the highest 1.85 on the morning of October $3 \mathrm{rd}$, with an average of 1.63 . This would be a proportion of ozone in the water of 0.658 grammes per cubic metre in the proportion used at present of 100 volumes of water to 40.4 of air.

The water and air are drawn together, by means of an injector, into the bottom of a sterilising tower (Fig. 3, page 38). This is a vertical cylinder of enamelled cast, iron constructed in sections, and divided at regular intervals by horizontal diaphragms consisting of carefully levelled and finely perforated trays made of celluloid, with holes $\cdot 7 \mathrm{~mm}$. $(\cdot 026$ inch) diameter, whereby the ascending current of gas and water is intimately mixed. In arldition the height of the column is sufficient to make the air 
Table I.-Chemical Results.

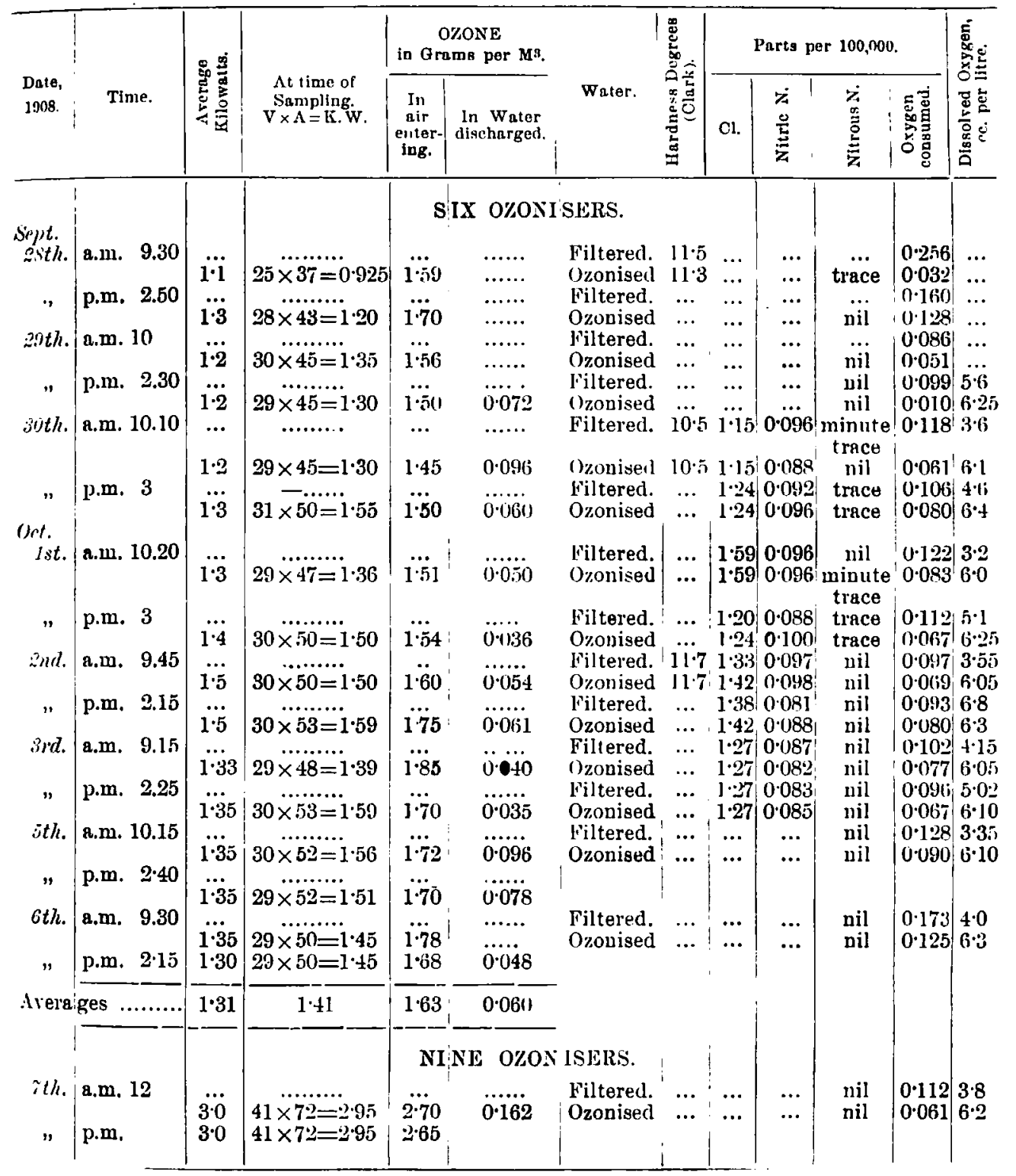

Note.-The above figures are calculated from the charts of the meters recording the watts, and the flow of the air and water treated. Copies of these charts accompany the report. The instruments were verifed by the agents of the Paris Municipal Service.-S. R. 


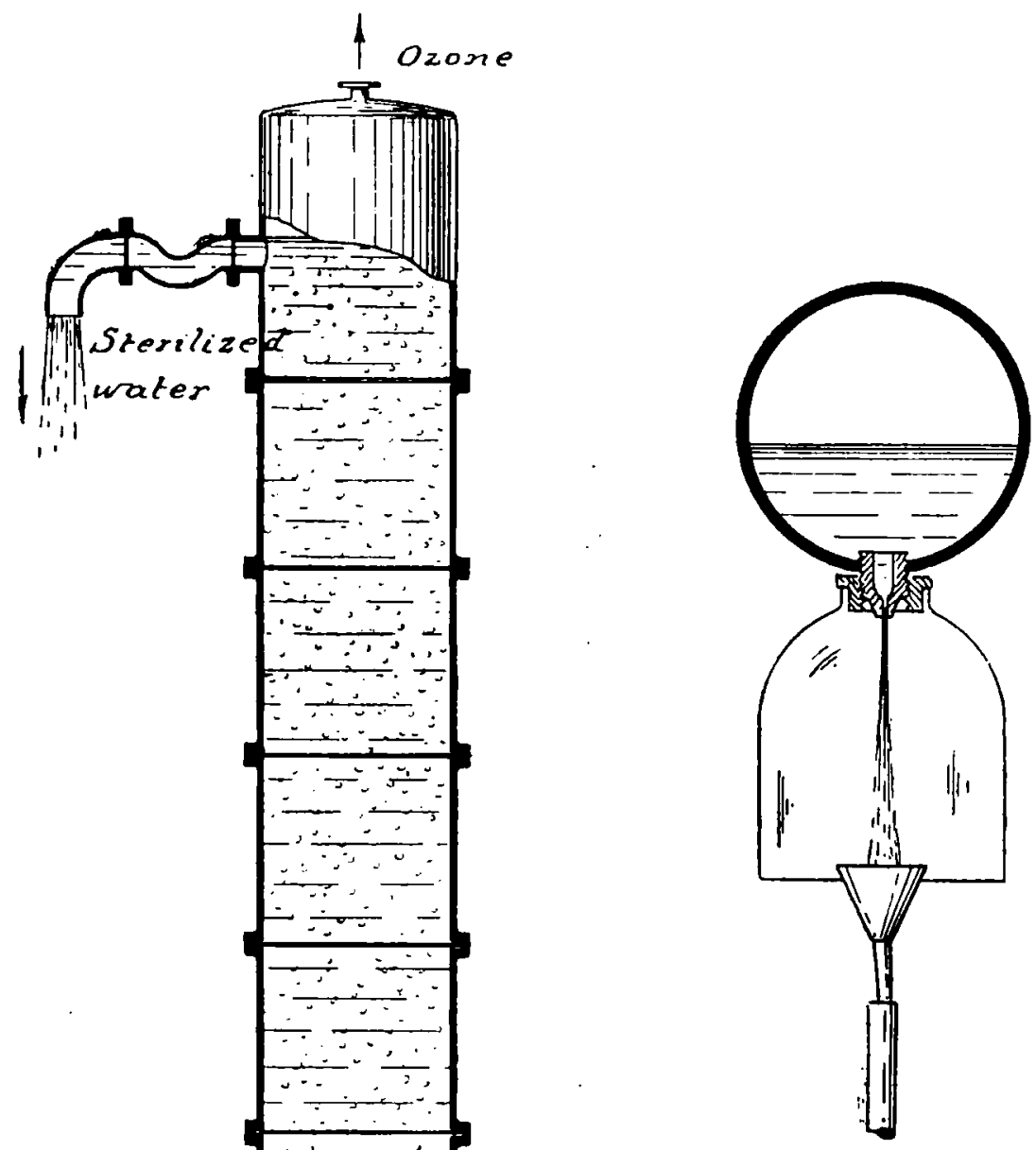

Fig. 4.

A section through the outlet pipe, from which, by means of a protected jet, a regular fraction of the ozonized water is withdrawn for testing. 
and water meet under an extra pressure of from 10 to 15 lbs. per square inch, which facilitates the absorption of the o\%one. The columns are provided at intervals with small glass windows for inspection, and with cockp for collecting samples. I noticed that the process of solution of the air was indicated by the bubbles becoming smaller ind less numerous as the tower was ascended, and in $m y$ chemical results (Table I., page 37) it will be seen that the oxygen dissolved in the filtered water entering is usually about 3 to 4 cubic centimetres per litre, whereas the escaping treated water is practically saturated with oxygen at the temperature, containing constantly about $6 \frac{1}{2}$ cubic centimetres per litre.

This fact in itself is a considerable advantage for the following reason. The aeration test, commonly accepted as a valuable index of the character of a natural water or an effluent (see my paper in the Analyst of August, 1901), shows that such a liquid is not ordinarily in a healthy condition unless it contains nearly its full complement of dissolved oxygen. If this be deficient it is a general sign that organic matter is using it up by the agency of bacteria, which is an objectionalle feature, as aeration alone is antagonistic to many pathogenic species. I have found that the amount of dissolved oxygen in the filtered water from the Marne is much below saturation, and my results are in agreement with those obtained by Drs. Ogier and Bonjean in 1904, hence the phenomenon appears to be constant, and points to stagnation and a want of arration in the filter beds.

The aerated and ozonised water flows from the top of the cylinders into an open collecting tank of white enamelled cast iron. During its passage through the columns it parts with a considerable portion of its ozone in oxidising the organic matter of the water, but it still retains a small excess of ozone dissolved, and in order to utilise this as much as possible in the purification the tank is divided into three chambers, so that the water flows through submerged orifices from the firs: compartment to the second, and then over the top of another partition into the third. In the discharge pipe just before entering into this reservoir a small exit, always running, and carefully protected by a glass bell jar, is placed for the periodical collection of samples (Fig 4). The physical features I observed constantly in the tank were:-

1. The change in the appearance of the liquid was very striking, from the dull greenish-brown of the filtrates to the bright sparkling and colourless or faint bluish tint of the treated water.

2. The odour of residual o\%one which was distinct in the first compartment had decreased in the second, and at the same time a 
large number of bubbles of gas were evolved; in the third the water had become almost inodorous. I allude later to $\mathrm{my}$ further observations on the slow continued action of ozone after the first effect.

A feature of the method is that in order to economise the fraction of ozone that passes away with the residual air from the top of the cylinders the process is worked in a cycle, and the escaping gases are strained, dried, cooled, re-ozonised, and used over again. To replace the gas absorbed, an automatic valve just above the top of the cylinder opens at very frequent intervals to admit fresh air.

Collection of Sumples for Anulysis. - I have taken special care that the samples should be fair and representative. Those of the filtered water were gathered from the underground collecting tank into which the mixed water from the filter beds flowed. I found that this filtrate required twenty to thirty minutes to reach and traverse the ozonising plant, therefore I took my samples of o\%onised water from the sampling bell jar already mentioned, thirty minutes after collecting the filtered water.

The course of the inquiry involved a number of chemical and physical questions which I was able to satisfactorily elucidate.

1. As to how far the temperatures are affected in the process. The solution of the gases in water, the oxidation of the organic matter by ozone, and the compression, all tend to produce an increase of temperature, while eraporation during the transit would effect a decrease. Atmospheric conditions might also have some influence. I therefore took observations of the temperatures of the filtered water throughout, and of the atmospheric conditions from October 1st to 7 th. The fluctuations during the latter period are shown as follows :-

\begin{tabular}{|c|c|c|c|c|c|}
\hline \multicolumn{3}{|l|}{ 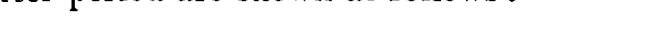 } & \multicolumn{3}{|c|}{ Temperatures, ${ }^{\circ} \mathrm{C}$} \\
\hline & Time. & & $\begin{array}{c}\text { Outside } \\
\text { Air. }\end{array}$ & $\begin{array}{c}\text { Filtered } \\
\text { Water. }\end{array}$ & $\begin{array}{l}\text { Ozonised } \\
\text { Water. }\end{array}$ \\
\hline \multirow[t]{2}{*}{ Oct. } & 1st -morning & fine & $20 \cdot 0$ & $18 \cdot 3$ & $18 \cdot 0$ \\
\hline & afternoon & 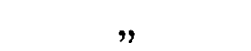 & $22 \cdot 5$ & $18 \cdot 5$ & $18 \cdot 2$ \\
\hline ()et. & $\begin{array}{l}\text { 2nd-morning } \\
\text { afternoon }\end{array}$ & $"$ & $\begin{array}{l}17 \cdot 5 \\
21 \cdot 0\end{array}$ & $\begin{array}{l}18 \cdot 4 \\
18 \cdot 2\end{array}$ & $\begin{array}{l}18 \cdot 0 \\
18 \cdot 0\end{array}$ \\
\hline \multirow[t]{2}{*}{ Oct. } & 3rd-morning & " & $17 \cdot 5$ & $18 \cdot 5$ & $18 \cdot 2$ \\
\hline & afternoon & , & $19 \cdot 5$ & $19 \cdot 0$ & $18 \cdot 1$ \\
\hline \multirow[t]{2}{*}{ Oct. } & 5th-morning & misty & $15 \cdot 0$ & $18 \cdot 0$ & $18 \cdot 1$ \\
\hline & afternoon & hot and sunny & $25 \cdot 0$ & $18 \cdot 5$ & $18 \cdot 2$ \\
\hline \multirow[t]{2}{*}{ ()et. } & 6th-morning & fine & $19 \cdot 0$ & $18 \cdot 5$ & $18 \cdot 0$ \\
\hline & afternoon & , & $21 \cdot 0$ & $18 \cdot 7$ & $18 \cdot 2$ \\
\hline \multirow[t]{2}{*}{ Oct. } & 7th-morning & " & $18 \cdot 3$ & $18 \cdot 0$ & $18 \cdot 0$ \\
\hline & afternoon & $"$ & $20 \cdot 0$ & $18 \cdot 8$ & $18 \cdot 0$ \\
\hline
\end{tabular}


These results prove :

(a) That the water under treatment instead of being heated is cooled to a slight extent, and that it issues at a constant temperature independent of that of the filtered water, or of atmospheric conditions during the time.

(b) That the cooling arrangements in the plant are working efticiently.

2. The question as to whether any corrosion of the apparatus by ozone occurred which could occasion metallic contamination of the water. My tests in this direction were entirely negative.

3. The possibility that oxides of nitrogen, chlorine compounds, or peroxicle of hydrogen might be formed in the process and remain in the water. That this is not so is established by my daily tests as recorded in Table I., page 37 ; neither the chlorine nor nitrate show any increase over the amounts naturally present in the filtered water: nitrites are usually absent, but are occasionally present in traces both in the filtered and in the ozonised liquids; a faint trace of hydrogen peroxide was discovered in only one case, on October 1st. The hardness was not altered. Saline anmonia in about an equally minute trace was sometimes found both in the filtered and treated waters.

4. The physical characters are greatly improved, and the organic matter, as shown by the oxygen-consumed figure, is considerably reduced. The average of 14 determinations showed a reduction from $\cdot 125$ parts per 100,000 to $\cdot 072$ parts, corresponding to a removal of 43 per cent. of the organic matter as judged by the oxygen-consumed standard. If this oxygen $(\cdot 125-072=.053$ parts) divided itself between the hydrogen and the carbon of the organic matter in the approximate diagrammatic manner $\mathrm{CH}_{2}+\mathrm{O}_{3}=\mathrm{H}_{2} \mathrm{O}+\mathrm{CO}_{2}$, it would produce a weight of $\mathrm{CO}_{2}$ very nearly equal to its own (48 to 44 ), or 0486 parts per 100,000 of $\mathrm{CO}_{2}$, corresponding to 0.486 grammes, or about 250 cubic centimetres, of carbonic acid per cubic metre of water. As a matter of fact $I$ found by experiment that the current of air in ascending displaced not only this carbonic acil but also a portion of that naturally present in the filtered water, so that the treated water contained a little less carbonic acid, and hence had a slightly lower acidity, but it was not therefore less aerated, as the loss of $\mathrm{CO}_{2}$ was more than compensated by the increase in the dissolved oxygen. This is shown very clearly by my results of October 6th :- 


\begin{tabular}{|c|c|c|c|c|c|c|c|}
\hline \multirow{3}{*}{$\begin{array}{l}\text { Filtered ... } \\
\text { Ozonised ... }\end{array}$} & \multirow{3}{*}{$\begin{array}{l}\cdots \\
\cdots\end{array}$} & \multirow{2}{*}{$\ldots$} & \multirow{2}{*}{$\cdots$} & \multicolumn{2}{|c|}{$\begin{array}{l}\text { Dissolved } \mathrm{CO}_{2} \text { per } \\
\text { cubic metre. }\end{array}$} & \multicolumn{2}{|c|}{$\begin{array}{l}\text { Dissolved oxygen per } \\
\text { culvic metre. }\end{array}$} \\
\hline & & & & $\begin{array}{c}\text { Gram. } \\
4.40\end{array}$ & $\begin{array}{c}\text { Cubic } \\
\text { centimetres. } \\
2,233\end{array}$ & $\begin{array}{l}\text { Gram. } \\
\therefore \cdot 72\end{array}$ & $\begin{array}{c}\text { Cubic } \\
\text { centimetres } \\
4,000\end{array}$ \\
\hline & & $\ldots$ & $\ldots$ & $1 \cdot 65$ & 537 & $9 \cdot 01$ & 6,300 \\
\hline $\mathrm{CO}_{2}$ reductios & nd & yget & & $2 \cdot 75$ & $-1,39 \dot{b}$ & $3 \cdot 29$ & $+2,300$ \\
\hline
\end{tabular}

The average of my determinations of the dissolved oxygen during 12 days was very close to the above, being per cubic metre of water:for the filtered, $6.36 \mathrm{grm}$. or $4,450 \mathrm{cc}$; and for the o\%onised, $8.87 \mathrm{grm}$. or $6,200 \mathrm{cc}$, showing an average gain of $2 \cdot 51 \mathrm{grm}$. or $1,750 \mathrm{cc}$. of dissolved oxygen.

On October 7th, when the oronisation was increased, the figures were as follows :-

\begin{tabular}{|c|c|c|c|c|c|c|}
\hline & \multicolumn{2}{|c|}{$\begin{array}{l}\text { Dissolved }\left(\mathrm{C}_{3} \text { per }\right. \\
\text { cubic mettre. }\end{array}$} & \multicolumn{2}{|c|}{$\begin{array}{l}\text { Dissolved ()xygen per } \\
\text { cubic metre. }\end{array}$} \\
\hline Filtered & 11 a.m. & $\ldots$ & $\begin{array}{c}\text { Gram. } \\
4 \cdot 18\end{array}$ & $\begin{array}{l}\text { Cubic } \\
\text { centimetres. } \\
2,122\end{array}$ & Graw. & $\begin{array}{c}\text { Cubic } \\
\text { centimetres } \\
\ldots\end{array}$ \\
\hline Ozonised & $11.30 \mathrm{a} . \mathrm{m}$. & $\ldots$ & $1 \cdot 87$ & 950 & $\ldots$ & \\
\hline Filtered & 2.30 p.m. & $\ldots$ & $3 \cdot 63$ & 1,843 & $5 \cdot 43$ & 3,800 \\
\hline Ozonised & 3 p.m. & $\ldots$ & $2 \cdot 42$ & 1,230 & 8.87 & 6,200 \\
\hline Filtered & 4.1.j p.m. $\quad \ldots$ & $\ldots$ & $4 \cdot 07$ & 2,066 & $\ldots$ & $\ldots$ \\
\hline Average ( & (). reduction .... & $\ldots$ & $1 \cdot 82$ & 914 & $\ldots$ & $\ldots$ \\
\hline Average 0 & xygen gain $\quad \ldots$ & $\ldots$ & $\ldots$ & $\ldots$ & $3 \cdot 44$ & 2,400 \\
\hline
\end{tabular}

5. The amount of ozone absorbed. When the ozonised air is kept regularly at $4(1) .4$ per cent. of the volume of filtered water treated, the ozone divides itself into three portions: (a) oxidising the organic matter in the water, $(b)$ dissolving in the water and passing out with it into the collecting tank, $(c)$ escaping with the air current at the top of the tower to be used again in the cycle. I have cletermined the o\%one left in the escaping air with the following results :-

On October 6th, with six ozoniser's acting as usual, the proportion of ozone in grammes per cubic metre was:

$\begin{array}{llll}\text { In the air entering at the bottom } \ldots & \ldots & \ldots & 1 \cdot 68 \\ \text { In the water entering }(40 \cdot 4 \% \text {, of } 1 \cdot 68=) & \ldots & \ldots & \cdot 679\end{array}$

Escaping $\left\{\begin{array}{llllll}\text { in the air } 40 \cdot 4 \% \text { of } \cdot 340) & \ldots & \cdot 137 \\ \text { in the water } & \ldots & \ldots & \cdot 048\end{array}\right\} \quad \ldots \quad r .185$

$\begin{array}{llll}\text { Used in oxidising the organic matter } & \ldots & \ldots & \cdot 494\end{array}$ 
Hence, nearly 73 per cent. is immediately utilised in purification, 7 per cent. remains dissolved in the water and may effect a further improvement, while about 20 per cent. passes off with the air-current. This proves that the De Frise cycle, in which the residual ozone is used again, is essential for economy.

The improvement as measured by acid permanganate in the ordinary oxygen consumed was :-

Oxygen consumed by the untreated

$$
\begin{aligned}
& \text { Granmes per Culjic metre. } \\
& \text {... } 1.73
\end{aligned}
$$

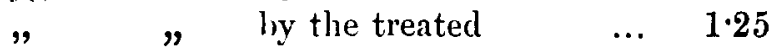$$
\text { Decrease } \quad \ldots \quad \ldots \quad \cdot 48(=28 \%)
$$

showing a close agreement with the above figures.

On ()ctober 7th, when the ozone was considerably increased by using nine ozonisers, the figures were as follows:-

In the air supply at the bottom Grammes per Cubic metre.

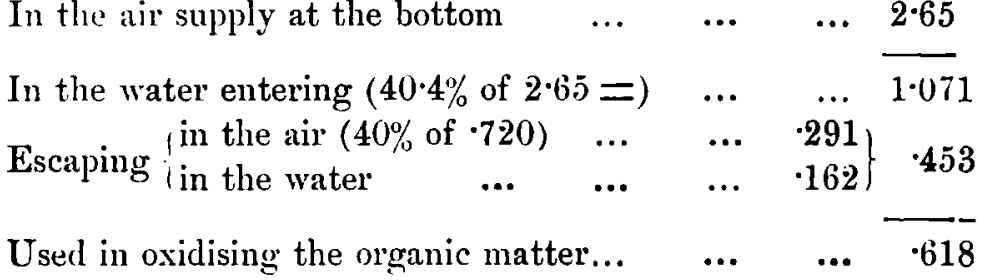

The filtered water was of a better character than that of the previous day, as judged by the permanganate figures :-

$$
\begin{aligned}
& \text { Oxygen consumed by untreated water } \ldots \quad \ldots \quad \ldots \quad 1 \cdot 12 \\
& \begin{array}{llllll} 
& \quad \quad \quad \quad \text { ly treated } & \ldots & \ldots & \ldots & \cdot 61 \\
\hline
\end{array} \\
& \text { Decrease } \quad \ldots \quad \ldots \quad \cdot 51(=45 \%)
\end{aligned}
$$

The percentage reduction is greater on account of the difference in the waters, but the actual oxidation is only a trifle more. A much higher proportion of ozone has escaped (27 per cent. insteal of 20 per cent. in the air and 15 per cent. instead of 7 per cent. in the water, making 42 per cent. in all), and the experiment shows that in regard to chemical results no proportional improvement was obtained.

6. The behaviour of the small quantity of ozone that passes out in the water.

I had noticed in the begimning of the inquiry that the odour and wone reaction disappeared in one or two hours, and it seemed probable, as alrearly suggested, that a further quantity of organic matter 
would be at the same time oxidised. That this idea is correct is shown by the following experiments made on the above two days:-

\begin{tabular}{|c|c|c|c|c|}
\hline & \multicolumn{4}{|c|}{ Oxygen consumed. } \\
\hline & \multicolumn{4}{|c|}{ October 6th. } \\
\hline & $\begin{array}{c}\text { grms. } \\
\text { per } m^{3} .\end{array}$ & $\begin{array}{l}\text { per cent. } \\
\text { reduction. }\end{array}$ & $\begin{array}{c}\text { grms. } \\
\text { per } \mathrm{m}^{3} \text {. }\end{array}$ & $\begin{array}{l}\text { per cent. } \\
\text { reduction. }\end{array}$ \\
\hline & $1 \cdot 73$ & & $1 \cdot 12$ & \\
\hline Ozonised water at first $\ldots$ & $1 \cdot 25$ & 28 & $0 \cdot 61$ & 45 \\
\hline Ozonised water 1 hour later & $1 \cdot 15$ & 34 & 0.58 & 48 \\
\hline Ozonised water 2 hours later & $0 \cdot 90$ & 48 & 0.51 & 54 \\
\hline
\end{tabular}

It is therefore evident that the figures given in this report measure the minimum amount of purification effected, and that in practice the water would on reaching its destination show still better chemical results.

They further show that the small quantity of ozone clissolved in the treated water does not remain as a permanent constituent, and that consequently as ozone is absent from the water when it reaches the consumer no physiological effects can be attributed to it.

Bacteriological Examination.-The samples were drawn from the same places as those taken for chemical examination. As already mentioned, the point at which the filtered water was examined was so far removed from the ozonisers that all danger of possible accidental germicidal action from traces of ozone was eliminated. As a rule two sets of Jacteriological observations were made on each day, in the morning and again in the afternoon, the ozonised water being collected after the plant had been running some time and at least thirty minutes after sampling the filtered water.

The organisms growing at $20^{\circ} \mathrm{C}$. were determined by means of nutrient gelatine cultures incubated for a minimum of three days, and the organisms at $37.5^{\circ} \mathrm{C}$ on agar plates examined after forty-eight hours incubation at blood-heat.

MacConkey's bile salt medium was employed for the coli tests, incubation being made for a minimum of forty-eight hours at $37 \cdot 5^{\circ} \mathrm{C}$. This method of testing for coli organisms is now extensively adopted in England and America; the results show, as a rule, higher frequency of coli than those obtained from the use of carbolic acid as the inhibiting reagent (phenol broth, etc.), and it is undoubtedly the more delicate test of the two. Acid growth with production of gas indicates a positive result $(+)$, so that the coli results are comparable with Dr. Houston's, London Metropolitan Water Board, "presumptive B. coli test." Negative results for coli were shown by entire absence of growth in the medium at $37.5^{\circ} \mathrm{C}$. (-) or by acid growth, but no evolution of gas. $\left(-^{*}\right)$. The results are given in Table II. 
Table II.-Bacteriological Results.

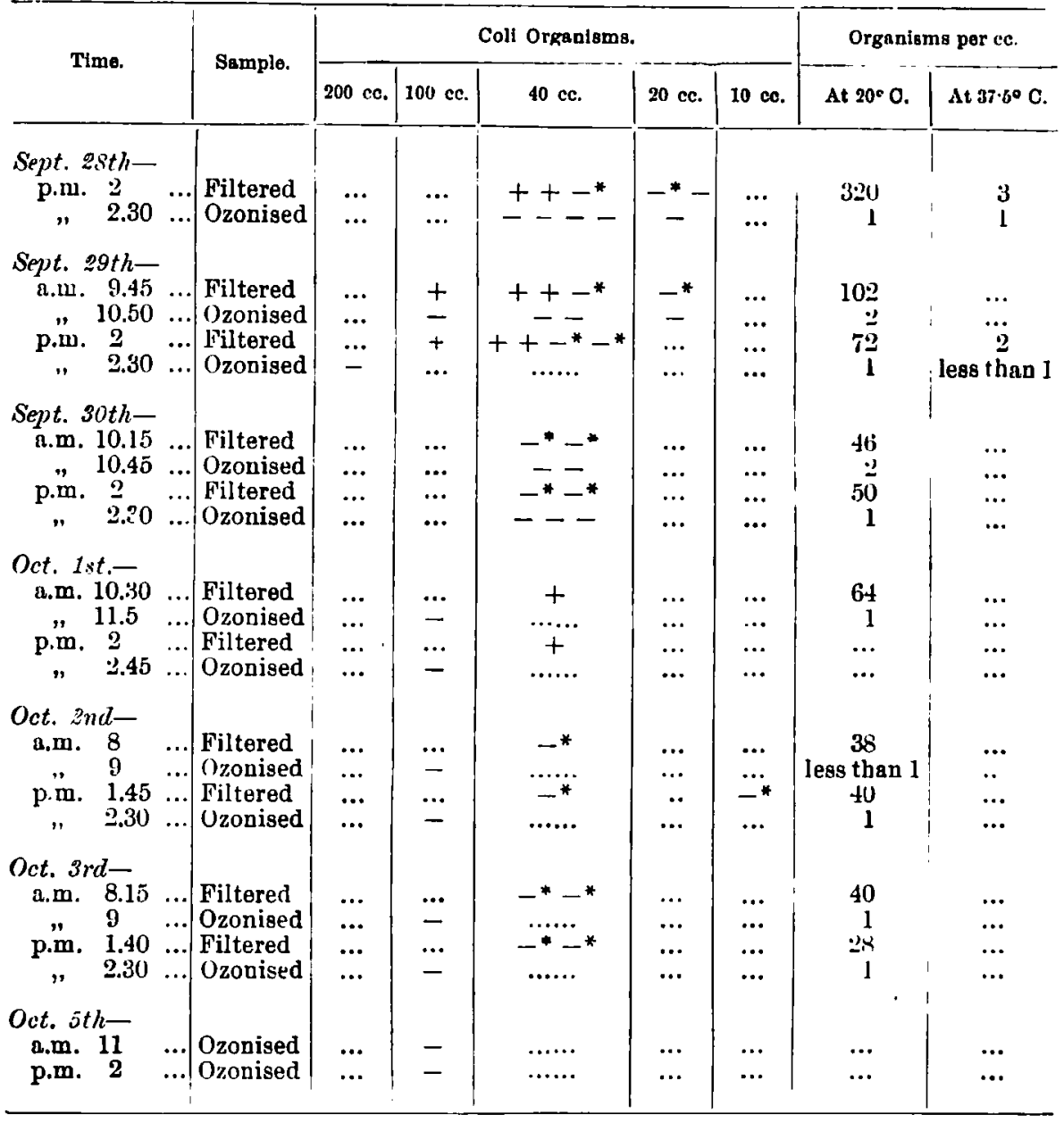

The filtered water showed considerable fluctuations in the total number of bacteria (organisms growing at $20^{\circ} \mathrm{C}^{\prime}$ ), and during the period corresponding to the continued dry weather a steady improvement in this respect was observed. The frequency of coli organisms during the period was about 1 per $100 \mathrm{cc}$. in the filtered water, out of twenty-two tests coli was found to be present eight times in $40 \mathrm{cc}$.

The ozonised water was found not to be sterile, but showed an average bacterial content of $1 \cdot 1$ per cc., these corresponding to innocuous sporebearing organisms of the subtilis type.

Entirely negative results were recorded in all cases for coli organisms 
in the ozonised water, no growth whatever being obtained in the MacConkey medium. During the testing a total volume of $1,580 \mathrm{cc}$. of the ozonised water was submitted for the coli test, with a maximum amount of $200 \mathrm{cc}$. at one test. The frequency of organisins in the filtered water, not producing gas but showing acid growth in the MacConkey medium at blood heat, reaching at times 1 per $10 \mathrm{cc}$. of water, is noticeable. This class of organism, whilst not having the significance of coli, is undesirable. They invariably accompany contamination to a greater extent than true coli, and in my opinion their frequency in the filtered water is an unsatisfactory sign.

In order to exclude any possible interference due to the presence of o\%one, the treated water was not examined until at least several minutes after collection. To remonstrate any retrugacle action in the ozonised water by short storage, samples of the filtered and ozonised water were kept (1) 24 hours at $0^{\circ}('$, and (2) $4 x$ hour: at room temperature. The ozonised water showed coli absent in both cases from $100 \mathrm{cc}$. (the maximum amount tested), and the filtered water showed coli present in $40 \mathrm{cc}$. and $50 \mathrm{cc}$. respectively:

The results of the bacteriological examination prove, as a gencral conclusion, that the ozone treatment destroys all lut the more resistant spore forms of bacteria present in the filtered water: coli and allied intestinal organisms are entirely eliminated, and $\leqslant$ ulsequent contamination being excluded, there is no recrudescence of this class of organism. The ozonised water during the period of the tests showed a uniformly constant degree of sterility as against a very variable bacterial content of the unozonised filtered water.

The water as leaving the sand filters at the St. Maur works, and augmenting the Paris supply, is decidedly inferior to the Lonclon water supply. Taking the coli test with 100 ec. of water as a methor of comparison, the former gives positive results approaching 100 per cent., whilst all London waters for the year ending March, 1908, showed $38 \cdot 6$ per cent. of positive results on this basis (presumptive $B$. coli test). The results with the ozonised water show that it is of far greater bacterial purity than that obtained by any adopted method of sand filtration or storage; the ozone treatment produces water which is superior to the high class London waters obtained from the Kent deep wells, or that have been suljected to natural filtration.

Application of the method.-It will now be useful to inquire under what conditions the ozone treatment of water for drinking purposes is indicated, and in this connection to make a comparison between the 
relative circumstances existing in Paris and in Lomlon. Both towns derive their drinking supplies partly from rivers and partly from wells, the latter giving water which has hitherto been regarderl as of sufficient purity to require no artificial purification, while the river-waters have for many years past been subjected to sand filtration. The amount of purification which a sand-filter is capable of ensuring depends upon the original purity of the river water to be treated: and as in hoth cases the rivers have been getting more and more contaminated with the growth of the upper riparian populations, it has been found that this purification does not now result in a water which is equal to the standard of deep well-supplies, and consequently there is no method of ensuring a given purity without largely: augmenting the number of existing filter-beds and at the same time maintaining a very efficient bacterial control. Thus in London at the present time the Water Board have 160 filter-beds, the greater number of which are in constant operation, and despite the very great number of samples examined day by day at the laboratories, water is constantly passing into public supply the quality of which has not been bar.terially determined. In Paris, as we have seen, it has been proposed to safeguard the purity of the water by an ozone treatment after the existing sand filtration, whilst in London during the last few years the Water Board have proposed to adopt storage of the crude river-water for a length of time sufficient to ensure the destruction of all or nearly all the typhoid bacilli, and so to prepare a water by this "safety change" that the existing filter-beds will continue to do satisfactory work. So much is this the case that the advisers of the Water Board of I ondon are of the opinion that a well stored rapidly filtered water is likely to be safer than an unstored slowly filtered water. From the work alreacly done in this direction, it would appear that in London the average impurity of the present raw river-waters is of such a character that no less than two months of storage would be necessary in order to ensure the death of all typhoid bacilli, and, as a compromise, it is suggested that provision should be made in London for a four weeks' storage before filtration. It is obvious that the length of time required to improve the quality of the water up to this safety standarl is greater than the number of clays which are necessary to ensure a sufficiency of quantity, and Dr. Houston, in his report, specially points out that after having provided a storage capacity of four weeks a slow rate of filtration should still be maintained at the existing filter works, so that no economy in the cost of filtration as ordinarily practised is to be expected, at any rate until after the new régime has had sufficient trials. But stored water may behave very differently to the unstored waters hitherto treated. The 
time taken to form the "Schmutzdecke" will probably be longer, as there is less sediment in the stored water, and hence the time during which the filter delivers water at the proper rate will be less than under present conditions. It would seem, therefore, if the conclusions of Dr. Houston are correct, that the proposal to increase the storage of the river water to four weeks must be accompanied by an increase of the number and area of the filter heds, if the rate of filtration is still to be maintained as at present. In order to ensure the storage of all the water supplied to London it is necessary to recollect that this amount can only be taken from the rivers Thames and Lea in the absence of both high flood and of drought, and consequently the existing storage reservoirs, at present holding nearly 40 times the daily average supply, will not only require rearrangement, but also suitable additional works hefore they can fulfil the conditions laid down. Hence the subject resolves itself into an engineering problem, and an inquiry whether the outlay on these additional works will secure the same quality as an ozone treatment of the existing water as it leaves the filters.

I understand the Paris municipality have decided to ozonise the whole of their Marne supply at St. Maur, equal to 90,000 cubic metres per day. The water to be treated will pass through the existing filters at twice the present rate, 16 feet instead of 8 feet per 24 hours. An ozone installation capable of treating 10 million gallons a clay (half the above quantity) by the system described in this paper will be erected at St. Maur, involving no further outlay for storage or filters. The whole of the water passing through the filters, whatever its coli content, will be ozonised at an expenditure of 135 B.T.U. per million gallons.

We have seen that under the ozone treatment an immediate chemical test gives the safety factor which is required for successful working in such a way that no doubt can be raised as to the purity of the water; but on the other hand by the present dependence on storage and filtration, although the safety change may be assumed to take place in the proposed reservoirs, the uncertainty of the quality of the water on leaving the filter beds still remains.

All towns with a river-water supply have at present conditions similar to those of Paris and London, and the reasons for an ozone treatment seem therefore applicable. Many other places whose conditions of supply involve drawing on wells which may be subject to occasional or periodic pollution could by this treatment ensure a guaranteed purity.

My general conclusions as the result of this investigation are that:-

(1) The ozone treatment of a filtered river water as carried out at 
St. Maur, Paris, Works by the De Frise process is a satisfactory method of ensuring a standard of purification for a municipal water supply equal to modern requirements.

(2) The De Frise process differs, in my opinion, from all previous attempts at water sterilisation by means of ozone in combining the De Frise steriliser and ozone recuperation system with the Siemens-De Frise ozoniser, which combination avoids the difficulties attending the use of the emulsifiers and sprayers which have been hitherto used for this purpose, and is attended with a low cost for renewals owing to breakages in the dielectric.

Professor Henry Robisson (Westminster) said the description of the apparatus used in Dr. Rideal's experiments, and the tabulated chemical and bacterial results, were interesting for reference, especially in regard to conditions similar to those dealt with in the paper. In connection with this it should be observed that other systems for utilizing ozone were now well known, so that the question of comparative cost and efficiency of the system employed at Marne, and of the others that were available, must not be overlooked.

Filtration alone would require to be on an exceptional scale for such polluted water, as at Marne, so that the employment of something additional was imperatively necessary.

It would, he thought, have been better if the paper had been confined to the experiments carried out with the foul water from the River Marne. To apply any results in regard to that river to the water supply of London must be characterized as out of place. London was supplied with as pure water as that of any town. The River Thames was becoming less and less polluted, and the effect of storing the Thames water in large reservoirs was, as everyone knew, to produce a self-purifying action. The water thus stored therefore only required a small amount of filtration, and did not require any ozonising process.

The question which the Water Board had to deal with, and were now dealing with, was the quantity that was necessary to meet the future requirements of the Metropolis to ensure a continuance of the supply to an increasing population, and of the same excellent quality.

The author stated that: "In order to insure the storage of all the water supplied to Loudon, it is necessary to recollect that this amount can only be taken from the rivers Thames and Lea in the absence of both high flood and of drought, and consequently the existing storage reservoirs, at present holding nearly forty times the daily average supply, will not only require re-arrangement, but also suitable additional works before they can fulfil the conditions laid down. Hence the subject resolves itself into an engineering problem, and an enquiry whether the outlay on these additional works will secure the same quality as an ozone treatment of the existing water as it leaves the filters."

YoL. $x . x x$. No. 1 . 
As the present filtration of Thames water was efficient, and the same would be continued in connection with the proposed extensions of the stornge of Thames water, it was difficult to appreciate the meaning of the last part of the foregoing quotation.

Lr.-Col. A. M. Davies (Eltham) said he had had no personal experience with any of the ozone systems of purification, but lad noted one or two points that had come up at the Berlin Congress in 1907, when this subject was considered in section VI. Dr. Erlwein, of Berlin, gave a bibliography of 38 memoirs on the process, from 1891 to 1907 : and, together with all the other speakers, expressed himself generally in farour of the principle of ozonising a water supply; he reviewed the various systems, and gave plans and details of working. Courmont and Lacomme, of Lyons, in ansther review of the subject, concluded that the process was only applicable to clear waters, i.e., waters at all turbid wonld need previous filtration or clarification. They considered the results obtained to be excellent, but not invariably so; which merely means that inspection by a responsible engineer is constantly required, the apparatus must work without interruption, and frequent bacterial examinations must be made ; on account of the cost of inspection and control, the installation would have to be a large one to make it pay. As to the bactericidal power, these observers found in the Marne water that $f, 000$ per c.c. were reduced to 7 , and $B$. coli was destroyed. Abriham and Marmier, at Emmerin, near Lille, found that 1517 per c.c. were reduced to 0.03 per c.c. : and at Cosne, on the Loire, that t,:38:s per c.c. were reduced to less than one per c.c., B.coli being destroyed. $\mathrm{B} y$ the Otto process, the germs in Seine water were reduced from 2,080 to less than one per c.c.; and at Nice, from 2,000 to 1.4 per c.c. ; in each case $B$. coli being destroyed. Chlopin and Dobrowoliky reported that the Neva water at St. Petersburg, treated by the Siemens-Halske method, had its bacteria reduced by 97 to 99 per cent. All these reports seem to show that effective bacterial purification takes place. In the discussion, it was agreed that the supervision must be most minute and sustained (except that $M$. Courmont stated that the Siemens-IIalske system was worked most snccesstully at Paderborn "under the sole direction of a single mechinic for two years:" and the De Frise system at St. Maur, by two mechanics and one labouler for three months). Lt.-Col. Davies was aware of instances in which excellent purification arrangements land broken down because the supervision required was of a highly skilled nature, not always afforded ; and thought it was much to be desired that some system of purification might be devised that would " run itself" as nearly as possible, without likelihood of breakdown or need of skilled supervision, minute and unceasing. But, is there any such system?

Mr. Arinur J. Mantis (Westminster) said the author referred to a few points on which be would be glad of further information. The author had mentioned the running expenses of the ozonising plant at Paris, but the really 
important figure was the total annual cost, including capital charges. Could he tell them the first cost of the plant in relation to the rolume treated ?

It seemed to be uneconomical to employ ozone for the oxidation of any large quantity of chemical impurity, but, where the amount of such impurity was small, there might be a saving if the adoption of sterilisation enabled them to dispense with filtration. Did the author think that this might sufely be done in the case of waters which were only slightly impure?

If sterilisation were considered unnecessary in ordinary circumstances for such a water supply as that of London, it might still be valuable in case of such an emergency as the infective pollution of a source of supply, provided that the necessary plant could be installed at short notice.

Mr. Elstox Divossirne (Chairman of the Antwerp Waterworks Co.) said he had been in close touch with the water supply of Paris since 1855, when he introduced the iron process inv'nted by Sir William Anderson and Sir Frederick Abel, this process having been adopted for the purification of water drawn $f_{r o m}$ the Seine, and in use for the supply of nearly one million people inbabiting 131 communes surrounding Paris, whose daily consumption now averaged 43 million gallons. He further was acyuainted with the St. Maur filtering plant, which he visited last in 1907 in company with members of the Association of Water Engineers. The De Frise ozonising plant was at work on the occasion of that visit. The statement made by Dr. Ricleal that the St. Maur municipal watelworks furmish a large portion of the water supply of Paris required considerable qualification. It was true that a large volume of unfiltered water was pumped from the Marne daily, but this water was sent exclusively into the mains of the "service publique," and none of it into the distributing system of the "service privi," or potable domestic supply. The latter supply is obtained solely from the four aqueducts which bring spring water.to Paris, supplemented in case of need by water drawn from the Seine and Mrme, and filtcred at the Ivry and St. Maur stations respectively. Of these two filtering plunts, that at Ivry was the largest, and was kept in readiness for public use, whereas he ventured to state that no filtered water was ever supplied to the population from the St. Maur filters, which were worked intermittently, and devoted mainly to the purposes of experiment. This fact was rely important in considering how far the supplementary treatment of the filtured water by ozone was requisite or justifiable as regards the additional cost it involved. On referring to the report by Dr. Miquel on the De Frise prucess recently published, he noticed that under Table I. of the results of experiments it was stated that the water experimented on was sand-filtered water brought from the Ivry waterworks, and that this water, which hat pasised through several miles of mains, contained an arerage of 255 bacteria per c.c., and no Bacillus coli in 1,250 c.c. Taking into account the method employed by Dr. Miquel, in which the bacteria were counted aftel 15 days' cultivation in a specially nutritive medium, the Irry water experimented on 
showed a high degree of bacteriological purity. He would here remark on the need experienced by water engineers and administrators for a standard scale by which the results of bacteriological analyses could be appreciated and compared. in a paper entitled "Notes on the Water Supply of Paris and Suburbs," which he read before the Association of Water Engineers, after the visit of its members to Paris in 1907 , he was able to give a striking illustration of the discrepancies of the figures resulting from a series of 45 weekly bacteriological analyses of the sane samples of water taken from the mains of the Compaguie des Eaux de la Bantieve and analysed under three different conditions. One analysis was made weekly at the municipal laboratory of Montsouris, where a special nutritive medium was employed, and the examination was made after 15 days' cultivation, the other two series of analyses being carried out at the company's laboratory, with a less active medium of culture, the bacteria being counted after 15 days and 48 hours respectively in these two series of analyses. The results showed that the multiplication of the microbe colonies was influenced by the nature of the nutritive medium employed and proceeded by geometrical progression relatively to the period of cultivation. Taking the colonies counted after 48 hours as the standard, the bacteria as counted by the Montsouris method multiplied 5,400 per cent. for the raw water and 317 per cent. for the filtered water, while the 15 days' period of cultivation obtained in the company's laboratory resulted in an increase of 521 per cent. for the raw water and 220 per cent. for the filtered water.

In his opening remarks Dr. Rideal claimed for the ozone process that it alone had the merit of causing no chemical alteration in the water treated. He (the spenker) must call attention to the fact that the iron process to which he had already referred also had this merit. He was not desirous of undervaluing the value of the ozone process. Its effect on colour was remarkable, and be had noticed at St. Maur how by the ozone treatment the well-known apple-green tint of filtered iron water was changed to the blue colour which one is accustomed to see in water drawn from the chalk. The spring-water supply of Paris has this beautiful blue colour, and in view of the local sentiment against the use of the most carefully filtered Seine water, the engineers of that city may be justified in advising that the additional cost of ozonising their well-filtered Seine supply should be incurred. In the majority of cases, however, the ozone process must be looked upon as an expensive luxury. The ascertained cost of about $\frac{1}{33} \mathrm{~d}$. per 1,000 gallons, is for the production of the ozone, and for the circulation of the water through the apparatus. It may fairly be assumed that the total cost, including maintenance of the plant and amortization ol capital, will approximate $1 \mathrm{~d}$. per 1,000 , which in the case of Seine water must be added to the cost of filtration. As a comparison, he might state that the total cost of the purification and filtration of Seine water, as carried out by the Compagnie Générale des Eaux for the supply of the Paris suburbs is $\frac{1}{4} \mathrm{~d}$. per 1,000 gallons, of which approximately one-half is in respect of amortization and interest on capital outlay, and the remainder of working expenses. 
Mr. Aglio Dibdin (Westminster) pointed out that the highest prizes awarded at Paris in 1908 were given to the Marmier-Abraham and Otto processes which are combined now under the Compagnie Genérali de l'Ozone, and that a ten-million gallon scheme has been decided upon at St. Maur in which these combined processes will be employed. He asked the opener if this was the other half of the whole scheme at St. Maur, the Otto-Marmier-Abrabam and De Frise processes taking half each.

He disagreed with the opinion of Dr. Rideal that the presence of acid-forming but not gas-forming organisms in a drinking water was a sign of contamination. He pointed out that such organisms may be found in numbers in natural supplies free from any suspicion.

He also objected to the statement that the Water Board had to build new works in order to effect the clestruction of all or neavly all the typhoid bacilli in Thames River water. He referred to Dr. Houston's recent investigations in which out of numerous samples no specific typhoid organism had been isolated. Nor had the speaker ever come across an instance of a typhoid organism being isolated from the sources of supply for London's drinking water. Ite wished to protest against any possible alarmist interpretation which could be placed on that part of the paper.

Mr. H. C. H. Shextox (Westminster) referred to the Guildford and Maidenhead experiments of Dr. Kanthack and Dr. Rideal, in which it was established that one gramme of available chlorine in the form of hypochlorite would sterilise 1.21 cubic meters of settling tank effluent, and 1.5 cubic meters of filtered sewage eflluent.

He urged that as a solution of hypochlorite of sodium could be produced in any one of four good electrolysers now on the market, using one B.T.U. for the production of from 152 to 200 grammes of available chlorine, sterilisation of water could be effected more economically by means of hypochlorite electrolytically produced than by ozone.

On the basis of 055 francs per B.T.U. assumed in Dr. Rideal's paper, the actual cost of production of hypochlorite would be about .0137 pence per thousand gallons, plus the cost of salt, making the total cost .027 pence per thousand gallons as compared with $1_{3} \mathrm{~d}$. in the case of ozone.

Speaking as a waterworks engineer, he must admit that the slowness with which the processes of sterilisation were being taken up was due to the fact that as a rule civil engineers regarded anything in the nature of a patented process with dislike and distrust. The reason was not far to seek. There was always the possibility of the manufacturer coming to grief and leaving the engineer to look after the apparatus, to keep it in order and to renew its working parts as they wore out, and so forth. This, when it did occur, meant a great deal of extra work and responsibility and even risk of discredit to the engineer, who would certainly receive no thanks or credit for simply producing a result which 
was always expected by bis employers. Thus the averuge engineer iras in no hurry to give himself the extra trouble of investigating the new processes.

Dr. Rideal had pointed out very clearly that assuming sterilisation to be as practically possible in England as in Paris, there was an enormous saving to be effected here in London. Storage reservoirs to be nsed solely for purification purposes becime unnecessary, and the rates of filtration might be increased There could no longer be any doubt that it was the duty of every waterworks engineer to make a most careful study and investigation of these processes, which not only promised to give us a mich purer water supply, but to lessen the cost of the works of construction. Might not the Cambridge authorities, for instance, find a simple way out of their present difficulty by the adoption of sterilisation as an alternative to the abandonment of their works recently reconmended by the Local Government Board as reported in the press.

Looking at these facts, it was apparent that if water authorities throughout. the country would spend more money upon scientific advice and upon the scientific control for their works, they would probably be able to sare an immense proportion of their capital expenditure.

Dr. DArid Sommentille (London) wrote:-The action of ozone on bacteria had been tested at intervals during the past quarter of a century, but satisfactory quantitative determinations were not obtained, because the conditions of test in each case differed from those in the others. Ir. Rideal had condensed into his paper a considerable quantity of valuable information, and doubtless that communication would form the starting point of more accurate work on the germicidal properties of ozone in water.

The trouble with all oxidising germicides was the associated dead organic matter encountered. Where the latter was present in large quantity that class of disinfectant failed. Without previous filtration an ozone process was useless in certain cases. Used as an addition to a good type of filtration, he considered that it should be welcomed by all. But if it were made a substitute for filtration to that degree in which the area of the filter was much encroached upon, or the rate of filtration sensibly increased, he would require further experimental data before accepting it as safe.

He agreed with Dr. Rideal that the kind of water treated influenced the schmutzdeke, and consequently the rate and type of filtration. Enough was now known of this subject to justify the statement that rapid filtration was dangerous. Perbaps Koch's $100 \mathrm{~mm}$. per hour should seldom be exceeded. In rivers like that at St. Maur the number and variety of bacteria were subject to considerable change, and in his opinion a large number of observations spread over a considerable period should be made before pronouncing on the competency of any process of sterilisation. Had Dr. Rideal made his observations in the present month of January, probably he would lave found the bacteria in the unfiltered water double the number obtaining at the beginning of October. As he had stated elsewhere in connection with mechinical filtration, he was dubious 
concerning rapid methods of filteringr potable waters. The time factor was most important, both in filtration and sedimentation. Bacteria of all types were effectually disposed of by sedimentation, assisted by the formation in the water of a flocculent and harmless hydrate, when sufficient time was allowed.

Is the amount and character of the organic matter attaching to pathogenic bacteria were of much importance in the prohlem of sterilisation, he would like to have seen figures for ammoniacal nitrogen and albuminoid nitrogen in Table $I$.

Rejurenation tests for $B$. coli would have been of some value. The American Committee on standard methods of water analysis required that in the bacteriological tests, in addition to a minimum number of tests, debilitation through unsuitable environment should be taken account of, and rejuvenation practised. It seemed to him that this was necessary in connection with ozone tests.

Dr. RIJEsL, in reply, promised to obtain from the engineer in charge of the Paris works the costs asked for, and stated tliat, with water comparatively free from organic matter, ozone treatment could displace biltration. Mr. Shenton wished to compare the costs of chlorine and ozone sterilisation. These he believerl were not much different from one another, and at a forthcoming meeting at the Faraday Society he hoped to be able to give the data for the two processes. His own view at present was that the electrolytic chlorine processes had a field of usefulness in denlingr with sewage effluents and in the. purification of waters containing comparatively large amounts of organic matter, whilst ozone was more practicable for the treatment of drinking waters. He agreed with Mr. Shenton that the difficulty at Cambridge might possibly be solved in the way suggested. Dr. Sommerrille's criticism that the bacterial efficiency of the process would vary with the season was answered by the fact that the French experts had obtained similar excellent results in the spring of 1908 when the river water was in a different bacterial condition. He must disagree with Professor Robinson as to the efficiency of the present water-supply to London quâ quality. Surely he could not have read the recent research reports and recommendations of Dr. I Touston. He agreed that its quality was better than the Paris supply at present, but be contended that it would be inferior to that of Paris after they had installed the ozone treatment there. What he wished to know was the relative cost of the Water Buard's present proposaly as against an alternative such as Paris had adopted.

Mr. Dibdin was correct in stating that Paris had recently arranged to treat a further quantity of the Marne supply by another process, designed by the Co. Générale de l'Ozone. In the report on the recent trials in which the De Frise process did not compete, Dr. Miquel recommended that no premium should be awarded to the Otto process, which had not given perfect results as to the elimination of $\mathrm{B}$. Coli, and the Committee finally gave a second prize to the Marmier-Abraham process and a third prize to the Duyk process. In the new plant for the additional supply a fresh form of sterilizer was to be used. 
In reply to Mrr. Easton Devonshire, both the Paris Municipal filtering plants, that for Marne water at St. Maur, built in 1897, and that for Seine water at Irry, have been and are still nsed to make up any deficiencies which may occur in the spring-water supply of Paris. Dr. Imbeaus, Anmuare des Distribition d'Eau gives on page $89+$ the following figures for the two works:-

\begin{tabular}{|c|c|c|c|c|}
\hline & \multirow{2}{*}{$\begin{array}{c}\text { Filtering Capscity } \\
\text { in gallons per } 24 \text { hours. }\end{array}$} & \multicolumn{3}{|c|}{ Average of Filtered Water actually delivered in gallong par day. } \\
\hline & & $189 !$ & 1000. & 1901. \\
\hline $\begin{array}{ll}\text { Irry } & \ldots \\
\text { St. Maur } & \ldots\end{array}$ & $\begin{array}{l}7,700,000 \\
5,50: 2,000\end{array}$ & $\begin{array}{r}132,000 \\
3,31,00,000\end{array}$ & $\begin{array}{r}94,600 \\
3,0 \cdot 25,000\end{array}$ & $\begin{array}{r}8,800 \\
1,08+.600\end{array}$ \\
\hline
\end{tabular}

Recently, the filtering capacity of the Ivry works having been doubled, the first call is as a rule made on the larger plant, but very often both plants have to work together. This has been the case during the last few weeks; every drop of filtered water which st. Maur as well as Irry can deliver is at present used as drinking water for the Paris supply.

The bacteriological analyses of the drinking water supplied to the Seine Department are made by the Paris Municipal Micrographical Service (director, Dr. Miquel). They consist of enumeration tests for the suburban communities, and of $B$. coli test for the Paris Gitered river water.

The enumeration tests are made in flat flasks used as culture-dishes. The medium used has the following composition :-

\begin{tabular}{llll|l} 
Peptone .. $\quad \ldots$ & $\ldots$ & $20 \mathrm{gr}$. & Gelatine, extra white, 100 to $120 \mathrm{gr}$.
\end{tabular}

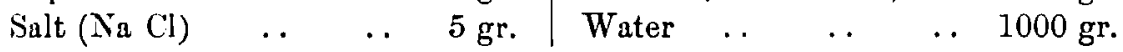

The mixture is neutralised with carbonate of potash.

The numerical determination of bacteria is made after 15 days of incubation. The relation between the number of colonies developed after from 1 to 15 days incubation at $20^{\circ} \mathrm{c}$., as deduced from the examination of more than 60,000 cultures, has been published by Drs. Miquel and Cambier on page 937 of their "Traité de bactóriologie."

When the Nanterne filters were started in 1906 , Dr. Miquel reported 500700 - 23,095 numberless colonies per cc. in their effluent against less than 300 or the water of another Seine water company, and the 400 allowed by contract. The company thought that something was wrong with Dr. Miquel's media or methods. But after the removal of a sample collecting device designed by the company, and after the filters had got accustomed to the company's servants, who had never attended similar apparatus, matters mended. Dr. Miquel reports for instance, the following figures for December, 1901 :

\begin{tabular}{|c|c|c|c|c|}
\hline & \multirow{2}{*}{$\begin{array}{l}\text { Date. } \\
1908 .\end{array}$} & \multirow{2}{*}{ - } & \multicolumn{2}{|c|}{ Number of bactes in per 1 cc. flttered Seine water. } \\
\hline & & & Choisy-le-Roi Anderson-process. & Nanterre Puech-Cbabal flters. \\
\hline \multicolumn{3}{|c|}{ 5th December.. } & \multirow{2}{*}{$\begin{array}{r}1 \cdot 195 \\
185\end{array}$} & \multirow{2}{*}{135} \\
\hline 7th & " & .......... & & \\
\hline 8 th & " & & . & 20 \\
\hline 14 th & " & .......... & 80 & 20 \\
\hline 2 ath & ," & & 75 & 6 \\
\hline 29 th & " & .......... & 100 & 15 \\
\hline
\end{tabular}


In 1904 the Paris authorities substituted the $B$. coli test to the enumeration of bacteria test for their filtered river water. They decided that no river water should be supplied as drinking water when it shows $B$. coli. The decision was taken not because $B$. coli were to be considered as objectionable, but because the $B$. coli test can be made within 24 hours, and makes a reliable criterium for the efficiency of the degree of purification the water has undergone. The Paris bacteriologists still use the phenol broth test, and have not as yet made use of MacRoutsey's medium in any official work. The introduction of this coli test proved disastrous to the two waterworks. which do not succeed in producing per year under the new rules more than one-third of the volume of filtered water they formerly did, and at times are often unable to produce a single drop of coli-free water as judged by this test.

A proposal to reduce the evil by increasing the number of filters at St. Maur was rejected by the sanitary authorities, and the experiments made at St. Maur by Mr. de Frise in 1905 and 1908. and for the Competition in 1907, having shown that ozone produced and used in different ways by different maliers eliminates $B$. coli from water filtered at twice the ordinary rate, a design was worked out for a plant to filter and sterilize at St. Maur about 20 million gallons of water per diem. To avoid creating a monopoly, it is proposed, as already mentioned, to divide the order for the ozone plant between two makers.

The economy made on the filters covers the cost of the ozone apparatus, and the cost of rapid filtration plus ozonisation, if superior to ordinary slow filtration, will be less than the cost of making water coli free by ordinary filtration, which, according to the experience learned at St. Maur with ordinary filters and at Ivry with Puech Chabal filters, would mean filtering at the rate of 8 feet per 24 hours, 30 million gallons of water to get 10 millions of it.

The cost of a plant for ozonising 10 million gallons of water per 24 hours is given by the engineer, Mr. Van der Made, as follows:-

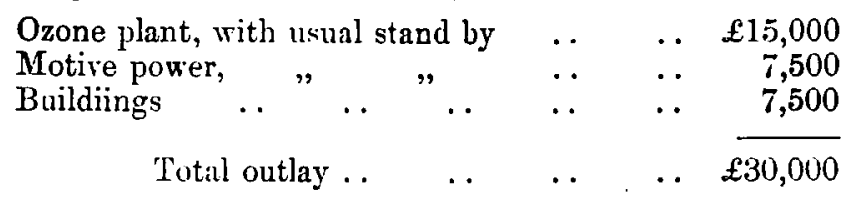

The annual expenses for running the plant night and day would be :-

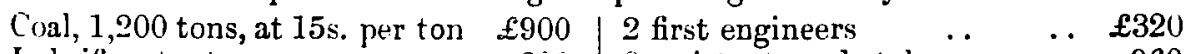

$\begin{array}{llllllll}\text { Lubrificant, etc. } & \ldots & \ldots & 200 & 8 \text { assistants and stokers } & \ldots & 960\end{array}$

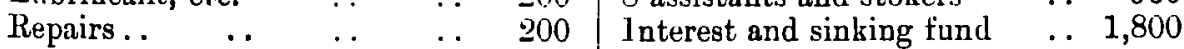

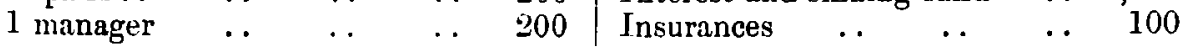

Total for $10,000,000 \times 365$ gals., which corresponds to about $\overline{£ t, 680}$

Dr. J. T. C. NAsil and Mr. G. T. Powell also took part in the discussion. 